\title{
IDENTIFICATION OF SOURCES OF RESISTANCE TO Meloidogyne enterolobii IN ACEROLA $^{1}$
}

\author{
JOHN LENNON FERRREIRA DOS SANTOS ${ }^{2}$, FLÁVIO DE FRANÇA SOUZA ${ }^{3}$, JERÔNIMO CONSTANTINO \\ BOREL $^{2}$, JOSÉ MAURO DA CUNHA E CASTRO ${ }^{3 *}$, ALEXANDRE SANDRI CAPUCHO ${ }^{2}$
}

\begin{abstract}
In Brazil, acerola trees infested by Meloidogyne enterolobii present lower yield and fruit quality. The use of rootstocks resistant to this pathogen is one of the alternatives to overcome this problem. This study aimed to assess the reaction of 22 acerola accessions to $M$. enterolobii, aiming to identify at least one resistant rootstock. The experiment was carried out in a randomized block design with 10 replications and each plot consisting of 10 plants. Each plant was inoculated with 350 eggs and second-stage juveniles of $M$. enterolobii, with the gall index (GI) and reproduction factor (RF) being determined after 90 days. The variables were analyzed using the mixed model methodology (REML/BLUP). The accessions ACO-13, ACO-14, ACO18, and BRS Apodi stood out with four to six plants showing resistance reaction to the root-knot nematode, but the assessment of accessions should be performed under a higher density inoculum and longer time.
\end{abstract}

Keywords: Malpighia emarginata. Root-knot nematode. Rootstock.

\section{IDENTIFICAÇÃO DE FONTES DE RESISTÊNCIA A Meloidogyne enterolobii EM ACEROLEIRA}

RESUMO - No Brasil, as aceroleiras, quando infectadas por Meloidogyne enterolobii, apresentam redução na produtividade e na qualidade dos frutos. Uma das alternativas para solucionar este problema é a utilização de porta-enxerto resistente a esse patógeno. O objetivo deste trabalho foi avaliar a reação de 22 acessos de aceroleira a $M$. enterolobii, visando identificar, pelo menos, um porta-enxerto resistente. $\mathrm{O}$ experimento foi conduzido em blocos ao acaso, com 10 repetições, sendo cada parcela formada por 10 plantas. Cada planta foi inoculada com 350 ovos mais juvenis de segundo estádio de $M$. enterolobii e, após 90 dias, foram determinados o índice de galhas (IG) e o fator de reprodução (FR). As variáveis foram analisadas pela metodologia de modelos mistos (REML/BLUP). Com base nas duas variáveis avaliadas, destacaram-se os acessos, ACO-13, ACO-14, ACO-18 e BRS Apodi com quatro a seis plantas com reação de resistência ao nematoide-das-galhas, mas a avaliação dos acessos deve ser feita sob maiores doses de inóculo e por tempo mais longo.

Palavras-chave: Malpighia emarginata. Nematoides-das-galhas. Porta-enxerto.

\footnotetext{
${ }^{*}$ Corresponding author

${ }^{1}$ Received for publication in 09/30/2020; accepted in 07/26/2021.

Paper extracted from the master thesis of the first author.

${ }^{2}$ Agronomy College, Universidade Federal do Vale do São Francisco, Petrolina, PE, Brazil; jh.agronomia09@gmail.com - ORCID: 00000003-1065-2881, jeronimo.borel@univasf.edu.br - ORCID: 0000-0002-5774-5607, alexandre.capucho@univasf.edu.br - ORCID: 00000003-1002-9969.

${ }^{3}$ Embrapa Semi-Arid, Empresa Brasileira de Pesquisa Agropecuária, Petrolina, PE, Brazil; flavio.franca@embrapa.br - ORCID: 0000-0002 -9632-2666, mauro.castro@embrapa.br - ORCID: 0000-0003-1345-6042.
} 


\section{INTRODUCTION}

Acerola cultivation in Brazil has been characterized by heterogeneous orchards with seedderived saplings, leading to many differences between plants, hindering management and harvesting, and negatively influencing yield and fruit quality. In addition, plants may present variable susceptibility reactions to many diseases (OLIVEIRA; SOARES FILHO; CUNHA, 1998; BRUNINI et al., 2004; LIMA et al., 2014).

In recent years, acerola orchards have shown a decrease in yield caused by the root-knot nematode (Meloidogyne spp.) parasitism. It is one of the main problems that affect the crop (CAVICHIOLI et al., 2014). Plants infected by these pathogens have lower water and nutrient absorption, with negative effects on the canopy and root system.

Due to the potential of $M$. enterolobii to cause damage to several crops, studies have been carried out aiming to found genetic resistance in acerola, but resistant genotypes have not yet been identified (SILVA; KRASUSKI, 2012).

Cavichioli et al. (2014) studied the reaction of five clones and three varieties of acerola to $M$. enterolobii and observed that all were susceptible to the nematode. Moreira et al. (2016) also studied the reaction and detected susceptibility in ten acerola accessions of the active germplasm bank at the Federal Rural University of Pernambuco, Brazil.

Methodologies used to select superior genotypes in perennial plants include the mixed model approach based on the restricted maximum likelihood (REML) and best linear unbiased prediction (BLUP), which obtains estimates of components of variance and predicted genetic gain (RESENDE, 2016). This methodology has been used for selection in several perennial crops, such as cashew (MAIA et al., 2009), coffee (PETEK; SERRA; FONSECA, 2008), eucalyptus (ROSADO et al., 2012), and acerola (PAIVA et al., 2007).

Thus, this study aimed to assess the reaction of 22 progenies of acerola accessions from the Brazilian Agricultural Research Corporation (Embrapa) genetic collection to M. enterolobii.

\section{MATERIAL AND METHODS}

The experiment was carried out from May to October 2016 at the Embrapa Semi-Arid, Petrolina, $\mathrm{PE}$, Brazil, in a climate-controlled greenhouse, with temperatures between $27{ }^{\circ} \mathrm{C}$ and $30{ }^{\circ} \mathrm{C}$ and $60 \%$ relative humidity. The reaction of the following progenies of acerola accessions was assessed: ACO-18, ACO-14, ACO-09, IAPAR-01, BRS Apodi, BRS Sertaneja, Olivier, Coopama N1, ACO15, Reci-02, ACO-05, Monami, ACO-13, ACO-10, Dominga, Lígia, Alha-06, Clone 47/1, ACO-19,
FP-19, Nikki, and Luísa. These accessions are maintained at the active germplasm bank (BAGAceroleira) at Embrapa Semi-Arid, located in Petrolina, Pernambuco State, Brazil.

Half-sib acerola progenies were formed from fruits of the 22 accessions collected separately and processed to obtain the seeds, which were sown on trays filled with vermiculite substrate to obtain the saplings. The plantlets were transplanted at 30 days after germination, when they developed the third pair of leaves, to $250 \mathrm{-g}$ cone-tainers with substrate previously sterilized in an autoclave at the proportion of $2: 1: 1 / 2$ (soil, vermiculite, and Multiplant ${ }^{\mathbb{R}}$ ). The saplings were irrigated daily and fertilized weekly with nutritive solution (HOAGLAND; ARNON, 1950).

The saplings, one per cone-tainer, were inoculated with 350 eggs and second-stage juveniles (J2) of M. enterolobii at 12 days after transplanting. The inoculum was applied using a pipette with automatic graduation into small holes made in the soil, close to the plant stem. The inoculum used came from a pure population, preserved in tomato cv. Santa Clara and the eggs were extracted according to the method proposed by Hussey and Barker (1973), modified by Boneti and Ferraz (1981). Subsequently, the suspension was adjusted to a concentration of 350 eggs and $\mathrm{J} 2 / \mathrm{mL}$ on Peters slides under an inverted light microscope, corresponding to 1.4 inoculum units per gram of substrate (BURLA et al., 2010).

The tomato cv. Santa Clara was used to confirming the inoculum viability of $M$. enterolobii. A randomized block design with 22 treatments and 10 replications was used. Each plot consisted of 10 seed-derived saplings.

The plants were assessed for the variables gall index (GI) and reproduction factor (RF) at 90 days after inoculation. GI was obtained from washed and counted plant roots, following a $0-5$ score scale: $0=$ no galls or egg masses, $1=1-2$ galls or egg masses, $2=3-10$ galls or egg masses, $3=11-30$ galls or egg masses, $4=31-100$ galls or egg masses, and $5=$ $>100$ galls or egg masses per root system (TAYLOR; SASSER, 1978). The acerola plants were considered resistant with scores 0,1 , and 2 and susceptible with scores 3, 4, and 5 (SASSER; CARTER; HARTMAN, 1984). RF was obtained by the quotient between the final and the initial population, and the plants were considered resistant when they presented $\mathrm{FR}<1$ and susceptible when $\mathrm{FR} \geq 1$ (OOSTENBRINK, 1966).

The quantitative traits were analyzed by the REML/BLUP linear mixed model method, using the statistical model 1 of the Selegen software (RESENDE, 2007), given by $\mathrm{y}=\mathrm{Xr}+\mathrm{Za}+\mathrm{Wp}+\mathrm{e}$, where $\mathrm{y}$ is the data vector, $\mathrm{r}$ is the vector of block effects (fixed), a is the vector of the additive genetic effects (random), $\mathrm{p}$ is the vector of the plot effects (random), e is the vector of the random error effects, 
and $\mathrm{X}, \mathrm{Z}$, and $\mathrm{W}$ are the incidence matrices for $\mathrm{r}$, a, and $p$, respectively. Genetic and phenotypic parameters were obtained based on the formulas $\hat{\mathrm{h}}_{a}^{2}=\frac{\sigma_{a}^{2}}{\sigma_{a}^{2}+\sigma_{c}^{2}+\sigma_{e}^{2}} \quad$ (narrow-sense individual heritability) and $\quad \hat{\mathrm{h}}_{\mathrm{mp}}^{2}=\frac{0.25 \sigma_{a}^{2}}{0.25 \sigma_{a}^{2}+\sigma_{c}^{2} / b+\sigma_{e}^{2} /(n b)}$ (narrow-sense heritability of the mean progeny), where $\sigma_{a}^{2}$ is the additive genetic variance, $\sigma_{c}^{2}$ is the variance between plots, $\sigma_{e}^{2}$ is the residual variance within the plot (environmental + non-additive), $\mathrm{CV}_{\mathrm{gi}} \%=\frac{\sqrt{\sigma_{\mathrm{a}}^{2}}}{\overline{\mathrm{X}}} \cdot 100$ (coefficient of individual genetic variation), $\quad \mathrm{CV}_{\mathrm{e}} \%=\frac{\sqrt{\sigma_{\mathrm{e}}^{2}}}{\overline{\mathrm{X}}} \cdot 100 \quad$ (experimental coefficient of variation), and $\hat{r}_{\text {gg }}$ (selective accuracy), expressed by the square root of the mean progeny heritability.

The best plants for resistance to $M$. enterolobii were selected according to the predicted genetic gain, based on the variables root-knot gall index (GI) and reproduction factor (RF). The best plants were chosen by applying a $1 \%$ selection pressure to individuals that presented the lowest genetic gain value since the studied variables had a negative character.

\section{RESULTS AND DISCUSSION}

The estimates of narrow-sense individual heritability $\left(\hat{\mathrm{h}}_{\mathrm{a}}^{2}\right) \quad($ Table 1$)$ presented a high magnitude for GI (0.68) and a medium magnitude for RF (0.42). The two traits had high magnitude values for the mean progeny heritability $\left(\hat{\mathrm{h}}^{2}{ }_{\mathrm{mp}}\right)$, with a higher estimate for GI (Table 1). Heritability is one of the most important genetic parameters, as it quantifies the fraction of the phenotypic variation that can be exploited in the selection (ROSADO et al., 2012). According to Berti et al. (2011), estimating genetic parameters is fundamental to predict gains from selection, as the gain occurs as a function of the heritable genetic variation of populations (additive genetic variance) from the genetic control (heritability) of the traits that are intended to improve, the selective accuracy, and the applied selection intensity.

Table 1. Estimates of the components of variance (individual REML) for resistance to Meloidogyne enterolobii in 22 acerola accessions.

\begin{tabular}{ccc}
\hline & \multicolumn{3}{c}{ Variable } \\
\cline { 2 - 3 } Estimate & Gall index & Reproduction factor \\
& $(\mathrm{GI})$ & $0.42 \pm 0.08$ \\
& $0.68 \pm 0.10$ & 0.8729 \\
$\hat{\mathrm{h}}^{2}$ & 0.9274 & 0.9343 \\
$\hat{\mathrm{h}}_{\mathrm{ap}}^{2}$ & 0.9630 & 70.6529 \\
$\hat{\mathrm{r}}_{\mathrm{gg}}$ & 27.7619 & 42.6162 \\
$\mathrm{CV}_{\mathrm{gi}} \%$ & 12.2759 & 9.1181 \\
$\mathrm{CV}$ & 77.3409 & \\
\hline Mean & &
\end{tabular}

$\hat{\mathrm{h}}_{\mathrm{a}}^{2}$ : narrow-sense individual heritability; $\hat{\mathrm{h}}_{\mathrm{mp}}^{2}$ : mean progeny heritability; $\hat{\mathrm{r}}_{\mathrm{gg}}$ : selective accuracy; $\mathrm{CV}_{\mathrm{gi}} \%$ : coefficient of individual genetic variation; $\mathrm{CV}_{\mathrm{e}} \%$ : coefficient of experimental variation.

The coefficients of individual genetic variation $\left(\mathrm{CV}_{\mathrm{gi}} \%\right)$ reached $27.76 \%$ for $\mathrm{GI}$ and $70.65 \%$ for RF (Table 1 ). This coefficient quantifies the magnitude of the genetic variations available for selection and, therefore, high values are desired (CARVALHO et al., 2016). According to Rosado et al. (2009), high $\mathrm{CV}_{\mathrm{gi}} \%$ values characterize the existence of genetic variability between individuals. Thus, a high $\mathrm{CV}_{\mathrm{gi}} \%$ value increases the chances of reaching genetic gains in plant selection. The coefficients of experimental variation $\left(\mathrm{CV}_{\mathrm{e}} \%\right)$ reached 12.27 for GI and 42.61 for RF. These values are considered low for the studied traits and lower than those found by Gomes et al. (2000), who studied resistance to $M$. javanica in acerola clones and reported coefficient of variation values of 20.57 for GI and 113.4 for RF. The low values found in this study for GI and RF correspond to good experimental quality.

The $\mathrm{CV}_{\mathrm{gi}} \%$ and $\mathrm{CV}_{\mathrm{e}} \%$ values reflect the accuracy magnitude $\left(\hat{\mathrm{r}}_{\mathrm{gg}}\right)$ (RESENDE; DUARTE, 2007). The mean accuracy was $95 \%$ for the two assessed traits. Moreover, according to the authors, high accuracy values indicate a good relationship between the predicted and actual values, which results in confidence for selecting agronomically superior plants.

According to Berti et al. (2011), estimating genetic parameters is fundamental to predict gains from selection, as the gain occurs as a function of the heritable genetic variation of populations (additive genetic variance) from the genetic control 
(heritability) of the traits that are intended to improve, the selective accuracy, and the applied selection intensity.

At first, the results indicate that the assessment of GI is more accurate than that of RF. However, both traits are important in resistance to nematodes. GI assesses the direct effect of the pathogen on the plant, while RF assesses its potential to increase the nematode population in the soil. Additionally, RF is the ratio between populations at different times, thus being more influenced by the environment. It is confirmed by heritability (mean progeny and individual) and CV estimates.

Higher estimate values were observed for $\hat{\mathrm{h}}_{\mathrm{mp}}{ }_{\mathrm{mp}}$ compared to $\hat{\mathrm{h}}_{\mathrm{a}}{ }_{\mathrm{a}}$ (Table 1). It is somewhat expected and has been observed in other studies (ARANTES et al., 2010; BERTI et al., 2011; ROSADO et al., 2012).

The relevant genetic variability between progenies, as well as the estimates of narrow-sense heritability at the individual level, indicates the possibility of success in selecting superior half-sib progenies for rootstock seed production and identifying promising individuals for cloning. It is particularly interesting in acerola because the species is easily propagated by seeds or cuttings. The accessions ACO-13, ACO-14, BRS Apodi, ACO-18, Olivier, Dominga, and FP-19 stood out for the frequency of plants with the number of root-knot galls lower than $10(6,4,4,2,1,1$, and $1 \%$ of the assessed plants, respectively) regarding the trait GI (Table 2).

Table 2. Frequency of plants (\%) according to the gall index (GI) of acerola accessions assessed for reaction to Meloidogyne enterolobii.

\begin{tabular}{|c|c|c|c|c|c|c|}
\hline \multirow{2}{*}{ Accession } & \multicolumn{6}{|c|}{ Frequency of plants $(\%)$ based on $\mathrm{GI}^{*}$} \\
\hline & 0 & 1 & 2 & 3 & 4 & 5 \\
\hline ACO-18 & 1 & $-^{* *}$ & 1 & 22 & 67 & 9 \\
\hline ACO-14 & - & 1 & 3 & 20 & 66 & 10 \\
\hline ACO-09 & - & - & - & 15 & 64 & 21 \\
\hline IAPAR & - & - & - & 7 & 55 & 38 \\
\hline BRS Apodi & - & - & 4 & 22 & 62 & 12 \\
\hline BRS Sertaneja & - & - & - & 1 & 54 & 45 \\
\hline Olivier & - & 1 & - & 1 & 55 & 43 \\
\hline Coopama & - & - & - & - & 50 & 50 \\
\hline ACO-15 & - & - & - & 7 & 74 & 19 \\
\hline Reci-02 & - & - & - & 1 & 60 & 39 \\
\hline ACO-05 & - & - & - & 1 & 56 & 43 \\
\hline Monami & - & - & - & 6 & 54 & 40 \\
\hline ACO-13 & 6 & - & - & 3 & 64 & 27 \\
\hline ACO-10 & - & - & - & 1 & 52 & 47 \\
\hline Dominga & 1 & - & - & 2 & 55 & 42 \\
\hline Ligia & - & - & - & 2 & 63 & 35 \\
\hline Alha-06 & - & - & - & - & 58 & 42 \\
\hline Clone-47 & - & - & - & - & 47 & 53 \\
\hline ACO-19 & - & - & - & 3 & 68 & 29 \\
\hline FP-19 & 1 & - & - & 7 & 67 & 25 \\
\hline Nikki & - & - & - & 3 & 66 & 31 \\
\hline Luísa & - & - & - & - & 52 & 48 \\
\hline
\end{tabular}

A $1 \%$ selection pressure was used on the 2,200 assessed plants, corresponding to 22 individuals, to select the best plants for the variable GI (Table 3). Applying high selection intensity is essential when attempting to reach genetic gain in a short period. The 22 best plants were selected based on the lowest predicted genetic gain values. The accessions ACO-13 and ACO-14 stood out among the 22 selected plants, as both presented a frequency of six resistant plants (Table 3 ). 
Table 3. Estimates of genetic gain for the 22 best acerola trees for resistance to Meloidogyne enterolobii based on the gall index (GI)

\begin{tabular}{cccccc}
\hline Ranking & Plot & Access & Plant & Gain & New mean \\
\hline 1 & 2 & ACO-18 & 10 & 0.0000 & 77.34 \\
2 & 3 & ACO-13 & 6 & 0.0264 & 77.36 \\
3 & 4 & ACO-14 & 8 & 0.0507 & 77.39 \\
4 & 2 & ACO-13 & 10 & 0.0749 & 77.41 \\
5 & 2 & ACO-13 & 6 & 0.0990 & 77.43 \\
6 & 6 & FP-19 & 3 & 0.1231 & 77.46 \\
7 & 4 & ACO-13 & 5 & 0.1471 & 77.48 \\
8 & 7 & ACO-18 & 2 & 0.1708 & 77.51 \\
9 & 4 & BRS Apodi & 9 & 0.1943 & 77.53 \\
10 & 7 & ACO-14 & 10 & 0.2177 & 77.55 \\
11 & 3 & ACO-18 & 10 & 0.2411 & 77.58 \\
12 & 1 & ACO-13 & 9 & 0.2642 & 77.60 \\
13 & 1 & ACO-13 & 1 & 0.2873 & 77.62 \\
14 & ACO-14 & 1 & 0.3104 & 77.65 \\
15 & 2 & BRS Apodi & 2 & 0.3335 & 77.67 \\
16 & 8 & BRS Apodi & 5 & 0.3564 & 77.69 \\
17 & 1 & ACO-14 & 1 & 0.379 & 77.72 \\
18 & 3 & ACO-14 & 3 & 0.4017 & 77.74 \\
19 & 5 & BRS Apodi & 7 & 0.4242 & 77.76 \\
20 & 1 & ACO-14 & 6 & 0.4465 & 77.78 \\
21 & Dominga & 9 & 0.4686 & 77.80 \\
\hline 2 & ACO-18 & 10 & 0.4907 & 77.83 \\
\hline
\end{tabular}

Tomato cv. Santa Clara proved the inoculant viability with an RF value equal to 23.22. Some of the 22 acerola accessions assessed for resistance to M. enterolobii stood out, presenting plants with 0 to 10 root-knot galls and $\mathrm{RF}<1$. The most promising accessions, with a higher frequency of plants resistant to $M$. enterolobii, were ACO-18 with $27 \%$, ACO-13 with 22\%, BRS Apodi with 17\%, ACO-14 with $14 \%$, and Coopama with $11 \%$ of the total of 100 plants assessed per accession (Table 4). It contrasted with GI, as a higher number of individuals was taken as resistant to $M$. enterolobii when RF was the trait used to designate plant resistance. It occurred because the RF value is given as a function of the ratio between the final and the initial population, which directly depends on whether the pathogen reproduces or not inside the host. The GI value is given by the number of galls formed in the root system. According to Ferraz and Brown (2016), root galls result from hyperplasia and hypertrophy reactions in cells due to infection caused by the nematode. Furthermore, the authors stated that the presence of root galls did not influence the development and production of the nematode inside the host, that is, FR is a more suitable characteristic than GI to assess the population growth of Meloidogyne species.

The RF trait was superior to the GI trait for assessing acerola resistance to $M$. enterolobii. According to Burla et al. (2010), RF was also superior to select Psidium spp. for resistance to the same nematode.

The best five out of the 22 accessions assessed for resistance to $M$. enterolobii, with the highest number of plants resistant to this pathogen, were selected (Table 5). The best accessions were selected for this variable instead of the best plants, as the plants were destroyed when the roots were ground to obtain the final population. The five best accessions were chosen due to their lower predicted genetic gain values and the accessions ACO-13, ACO-18, and BRS Apodi presented the highest number of resistant plants, with $\mathrm{RF}<1$. 
Table 4. Frequency (\%) of resistant and susceptible plants, according to the reproduction factor (RF) in acerola accessions assessed for resistance to Meloidogyne enterolobii.

\begin{tabular}{ccc}
\hline & \multicolumn{2}{c}{ Frequency of plants (\%) based on RF } \\
\cline { 2 - 3 } Accession & $\mathrm{RF}<1$ & $\mathrm{RF} \geq 1$ \\
\hline ACO-18 & 27 & 73 \\
ACO-14 & 14 & 86 \\
ACO-09 & 1 & 99 \\
IAPAR & 1 & 99 \\
BRS Apodi & 17 & 83 \\
BRS Sertaneja & 2 & 98 \\
Olivier & 3 & 97 \\
Coopama & 11 & 89 \\
ACO-15 & 3 & 97 \\
Reci-02 & 0 & 100 \\
ACO-05 & 0 & 100 \\
Monami & 1 & 99 \\
ACO-13 & 22 & 78 \\
ACO-10 & 2 & 98 \\
Dominga & 1 & 99 \\
Ligia & 8 & 92 \\
Alha-06 & 4 & 96 \\
Clone-47 & 0 & 100 \\
ACO-19 & 4 & 96 \\
FP-19 & 1 & 99 \\
Nikki & 0 & 98 \\
Luísa & & 900 \\
\hline
\end{tabular}

Table 5. Estimates of genetic gain of the five best acerola accessions for resistance to Meloidogyne enterolobii based on the reproduction factor (RF).

\begin{tabular}{cccc}
\hline Ranking & Accession & Gain & New mean \\
\hline 1 & ACO-18 & 0.0000 & 9.1118 \\
2 & ACO-13 & 0.5362 & 9.6543 \\
3 & Coopama & 0.9967 & 10.1148 \\
4 & BRS Apodi & 1.4151 & 10.5332 \\
5 & ACO-14 & 1.8741 & 10.9922 \\
\hline
\end{tabular}

Resistant genotypes are an effective and economical measure to be applied in the control of phytosanitary problems in the most diverse crops of economic importance. Thus, Embrapa Semi-Arid has conducted studies in search of acerola rootstocks resistant to Meloidogyne spp. In addition to the importance that genetic resistance has in combating these nematodes, its application can contribute to the expression of results obtained when using other measures based mainly on the cultural control method.

\section{CONCLUSIONS}

The mean progeny heritability for the two assessed variables showed high magnitude values, thus providing a favorable condition for the selection of resistant plants with high accuracy. The accessions ACO-13, ACO-14, ACO-18, and BRS Apodi presented the highest number of plants resistant to $M$. enterolobii, according to the results of the two assessed variables (GI and RF). Resistance assessments in acerola accessions must be performed with the application of higher inoculum doses and a longer period of exposure of the plants to the nematode.

\section{ACKNOWLEDGMENTS}

The first author thanks the Foundation for the Support of Science and Technology of the State of Pernambuco, Brazil (FACEPE) for granting the 
scholarship. This study was funded by the Coordination for the Improvement of Higher Education Personnel, Brazil (CAPES) and the Brazilian Agricultural Research Corporation (Embrapa).

\section{REFERENCES}

ARANTES, F. A. et al. Ganho genético com base no tamanho efetivo populacional de progênies de seringueira. Pesquisa Agropecuária Brasileira, 45: 1419-1424, 2010.

BERTI, C. L. F. et al. Variação genética, herdabilidades e ganhos na seleção para caracteres de crescimento e forma em teste de progênies de polinização aberta de Eucalyptus cloeziana. Revista do Instituto Florestal, 23: 13-26, 2011.

BONETI, J. I. S.; FERRAZ, S. Modificação do método de Hussey \& Barker para extração de ovos de Meloidogyne exigua de raízes de cafeeiro. Fitopatologia Brasileira, 6: 553-553, 1981.

BRUNINI, M. A. et al. Caracterização física e química de acerolas provenientes de diferentes regiões de cultivo. Revista Brasileira de Fruticultura, 26: 486-489, 2004.

BURLA, R. S. et al. Comparação entre níveis de inóculo, época de avaliação e variáveis para seleção de Psidium spp. visando à resistência a Meloidogyne mayaguensis. Nematologia Brasileira, 34: 82-90, 2010.

CARVALHO, L. P. et al. Uso da metodologia REML/BLUP para seleção de genótipos de algodoeiro com maior adaptabilidade e estabilidade produtiva. Bragantia, 75: 314-321, 2016.

CAVICHIOLI, J. C. et al. Reação de aceroleira (Malpighia emarginata DC.) à Meloidogyne enterolobii. Revista Brasileira de Fruticultura, 36: 156-160, 2014.

FERRAZ, L. C. C. B.; BROWN, D. J. F. Principais nematoides endoparasitas sedentários: nematoides de galhas e nematoides de cistos. In FERRAZ, L. C. C. B.; BROWN, D. J. F. (Eds.) Nematologia de plantas: fundamentos e importância. Manaus, AM: Norma Editora, 2016. cap. 7, p. 135-150.

GOMES, J. E. et al. Resistência de clones de acerola (Malpighia emarginata D.C.) a Meloidogyne javanica em condições de casa de vegetação. Nematologia Brasileira, 24: 65-67, 2000.

HOAGLAND, D. R.; ARNON, D. I. The water culture method of growing plants without soil.
Berkeley: University of California, 1950. 32 p.

HUSSEY, R. S.; BARKER, K. R. A. Comparison of methods for collecting inocula of Meloidogyne spp. including a new technique. Plant Disease Reporter, 57: 1025-1028, 1973.

LIMA, E. M. et al. Reação de clones de aceroleira a Lasiodiplodia theobromae. Enciclopédia Biosfera, 10: 1616-1622, 2014.

MAIA, M. C. C. et al. Seleção simultânea para produção, adaptabilidade e estabilidade genotípicas em clones de cajueiro, via modelos mistos. Pesquisa Agropecuária Tropical, 39: 43-50, 2009.

MOREIRA, A. A. et al. Response of Malpighia emarginata active germplasm bank accessions to Meloidogyne enterolobii parasitism. Genetics and Molecular Research, 15: 1-7, 2016.

OLIVEIRA, J. R. P.; SOARES FILHO, W. S.; CUNHA, R. B. A cultura da acerola no Brasil. Cruz das Almas, BA: EMBRAPA, 1998. 35 p.

OOSTENBRINK, M. Major characteristics of the relation between nematodes and plants. Mededeelingen der Landbouw-Hoogeschool, 66: 1 $-46,1966$.

PAIVA, J. R. et al. Acerola plant selection and breeding value predication in second selection cycle progenies. Crop Breeding and Applied Biotechnology, 7: 125-132, 2007.

PETEK, M. R.; SERRA, T.; FONSECA, I. C. B. Predição de valores genéticos aditivos na seleção visando obter cultivares de café mais resistentes à ferrugem. Bragantia, 67: 133-140, 2008.

RESENDE, M. D. V. Software SELEGEN-REML/ BLUP: sistema estatístico e seleção genética computadorizada via modelos lineares mistos. Colombo: EMBRAPA, 2007. 359 p.

RESENDE, M. D. V.; DUARTE, J. B. Precisão e controle de qualidade em experimentos de avaliação de cultivares. Pesquisa Agropecuária Tropical, 37: 182-194, 2007.

RESENDE, M. D. V. Software SELEGEN-REML/ BLUP: a useful tool for plant breeding. Crop Breeding and Applied Biotechnology, 16: 330-339, 2016.

ROSADO, A. M. et al. Ganhos genéticos preditos por diferentes métodos de seleção em progênies de Eucalyptus urophylla. Pesquisa Agropecuária Brasileira, 44: 1653-1659, 2009. 
ROSADO, A. M. et al. Seleção simultânea de clones de eucalipto de acordo com produtividade, estabilidade e adaptabilidade. Pesquisa Agropecuária Brasileira, 47: 964-971, 2012.

SASSER, J. N.; CARTER, C. C.; HARTMAN, K. $M$. Standardization of host suitability studies and reporting of resistance to root-knot nematodes. Raleigh: North Caroline State University Graphics, 1984. 7 p.

SILVA, G. S.; KRASUSKI, I. A. Reação de algumas espécies frutíferas tropicais a Meloidogyne enterolobii. Nematologia Brasileira, 36: 1-2, 2012.

TAYLOR, A. L.; SASSER, J. N. Biology, identification and control of root-knot nematodes (Meloidogyne spp.). Raleigh: North Carolina State University Graphics, 1978. 111 p. 